ISSN 0258-7122

Bangladesh J. Agril. Res. 40(4): 607-618, December 2015

\title{
VARIABILITY, CORRELATION AND PATH CO-EFFICIENT ANALYSIS OF BITTER GOURD (Momordica charantia L.)
}

\author{
M. H. KHAN ${ }^{1}$, S. R. BHUIYAN ${ }^{2}$, K. C. SAHA ${ }^{3}$ \\ M. R. BHUYIN ${ }^{4}$ AND A. S. M. Y. ALI
}

\begin{abstract}
Seventeen genotypes of bitter gourd (Momordica charantia L.) were studied in a field experiment conducted at the experimental field of Sher-e-Bangla Agricultural University, Dhaka, during April 2009 to September 2010. The objectives of the study were to measure the variability among the genotypes for yield and yield contributing characters, estimate genetic parameters, association among the characters and their contribution to yield. There was a great deal of significant variation for all the characters among the genotypes. Considering genetic parameters high genotypic co-efficient of variation (GCV) was observed for branches per vine, yield per plant and number of fruit per plant whereas low genotypic co-efficient of variation (GCV) was observed for days to first male and female flowering. In all the cases, it was found that phenotypic co-efficient of variation was greater than genotypic co-efficient of variation. Highest genotypic and phenotypic co-efficient of variation was observed in branch per vine, fruit length, fruit weight and number of fruit plant which indicated a wide variability among the genotypes and offered better scope of selection. The results obtained showed that fruit length showed low direct and positive effect on yield per plant and indirect positive effect on yield per plant via fruit diameter and average fruit weight. Similar result was found for fruit diameter. Average fruit weight and number of fruits per plant showed high direct and positive effect on yield per plant. Path analysis revealed that average fruit weight, number of fruits per plant, days to male flowering and fruit length had positive direct effect on fruit yield. Considering group distance and the agronomic performance, the inter genotypic crosses between G2\& G5; G2\&G14; G14\&G15; G2\&G15; G10\&G11; G10\&G13; G11\&G13; G5\&G15; G5\&G14 might be suitable choice for future hybridization programme.
\end{abstract}

\section{Introduction}

Bitter gourd (Momordica charantia L.), is one of the most important and a popular cucurbit vegetable grown in Bangladesh. Bitter gourd contains a reasonable amount of different nutrients such as proteins, carbohydrates, fats, minerals and vitamins A, B2, and C etc. Raja et al. (1984) reported very high amount of vitamin $C(95 \mathrm{mg} / 100 \mathrm{~g})$ and protein $(930 \mathrm{mg} / 100 \mathrm{~g})$ in some Indian bitter gourd variety. The fruits are bitter to taste due to the presence of substance

${ }^{1}$ Scientific Officer (Plant Breeder), ORC, ${ }^{3-5}$ Scientific Officer, Bangladesh Agricultural Research Institute (BARI), ${ }^{2}$ Professor, Dept. of Genetics \& Plant Breeding, Sher-eBangla Agricultural University, Dhaka, Bangladesh. 
called cucurbitacin. Bitter gourd is also reported against diseases like paralysis, indigestion and vomiting pain and diabetes (Mier and Yaniv, 1985). According to BBS (2009-10) total area of bitter gourd in Bangladesh was 22143 acres, per acre yield was $1871 \mathrm{~kg}$ and production was 41419 M.ton. Bitter gourd may contribute to the nutritional shortage of the people of Bangladesh. Particularly, it can provide added proteins, minerals and vitamins to the diet. There are a lot of variabilities among the existing bitter gourd germplasm of Bangladesh. An understanding of the nature and magnitude of the variability among the genetic stocks of bitter gourd is of prime importance for the breeder. A good knowledge of genetic wealth might also help in identifying desirable cultivars for commercial production. Because of its nature of high cross pollination, hardly any genetically pure strain is available to the growers. The basic key to a breeder is to develop high yielding varieties through selection, either from the genotypes or from the segregants of a crop. Expression of different plant character is controlled by genetic and environmental factors. So, the study of genetic parameters is necessary for a successful breeding program which will provide valuable information on the mode of inheritance of different characters which would be useful in selecting plants having desirable characters to develop new varieties. In a hybridization program knowledge of interrelationship among and between yield and yield components is necessary. Thus, determination of correlation between the characters is a matter of considerable importance in selection. Path analysis partitions the components of correlation co-efficient into direct and indirect and visualizes the relationship in more meaningful way (Bhatt, 1973). Among the local cultivated varieties, a wide range of genetic variability exists in this crop which can be exploited for its improvement. The basic key to a breeder is to develop high yielding varieties through selection, either from the genotypes or from the segregants of a crop. Expression of different plant character is controlled by genetic and environmental factors. So, the study of genetic parameters is necessary for a successful breeding program which will provide valuable information on the mode of inheritance of different characters which would be useful in selecting plants desirable characters to develop new varieties of bitter gourd in the country.

\section{Materials and method}

Seventeen genotypes of bitter gourd were used for the present research work. The genetically pure and physically healthy seeds of these genotypes were collected from different location. The name and source of collection of these genotypes are presented in Table 1. The experiment was laid out in Randomized Complete Block Design (RCBD) with three replications. The genotypes were distributed into the every plot of each block of the experiment. The individual plot was $3 \mathrm{~m}$ $\times 1 \mathrm{~m}$ in size. The seventeen genotypes of the experiment were assigned at random into plots of each replication. The distance maintained spacing row to 
row $50 \mathrm{~cm}$ and plant to plant $2 \mathrm{~m}$. The distance maintained between two blocks was $1 \mathrm{~m}$. Seeds of different accessions were sown in the pit on $5^{\text {th }}$ May, 2010.Germination of seeds were completed within twelve days and in each pit four seeds were sown and the soil around the plant was firmly pressed by hand.

Table 1. Name and sources of seventeen Bitter gourd genotypes used in the present study.

\begin{tabular}{c|ccc}
\hline Sl. No. & Genotypes No. & Source \\
\hline 1 & $\mathrm{G}_{1}$ & Siddiq Bazar, Gulistan, Dhaka \\
2 & $\mathrm{G}_{2}$ & Siddiq Bazar, Gulistan, Dhaka \\
3 & $\mathrm{G}_{3}$ & Narayanganj local market \\
4 & $\mathrm{G}_{4}$ & Agargaon local market, Agargaon, Dhaka \\
5 & $\mathrm{G}_{5}$ & Siddiq Bazar, Gulistan, Dhaka \\
6 & $\mathrm{G}_{6}$ & Agargaon local market, Agargaon, Dhaka \\
7 & $\mathrm{G}_{7}$ & Agargaon local market, Agargaon, Dhaka \\
8 & $\mathrm{G}_{8}$ & Siddiq Bazar, Gulistan, Dhaka, \\
9 & $\mathrm{G}_{9}$ & Narayanganj local market \\
10 & $\mathrm{G}_{10}$ & Kawran bazar,Dhaka \\
11 & $\mathrm{G}_{11}$ & Kawran bazar,Dhaka \\
12 & $\mathrm{G}_{12}$ & Narayanganj local market \\
13 & $\mathrm{G}_{13}$ & Agargaon local market, Agargaon, DhAka \\
14 & $\mathrm{G}_{14}$ & Siddiq Bazar, Gulistan, Dhaka, \\
15 & $\mathrm{G}_{15}$ & Kawran bazar,Dhaka \\
16 & $\mathrm{G}_{16}$ & Agargakn local market, Agargaon, Dhaka \\
17 & $\mathrm{G}_{17}$ & Narayanganj local market \\
\hline
\end{tabular}

The experiment plot was prepared by several ploughing and cross ploughing followed by laddering and harrowing with tractor and power tiller to bring about good tilth in the middle week of February 2010. Weeds and other stables were removed carefully from the experimental plot and leveled properly. After final land preparation, pits of $50 \mathrm{~cm} \times 50 \mathrm{~cm} \times 45 \mathrm{~cm}$ were prepared in each plot with a spacing of $3 \mathrm{~m} \times 1.25 \mathrm{~m}$. The dose of manure and fertilizers used in the study are Cow dung 10 ton/ha, Urea $150 \mathrm{~kg} / \mathrm{ha}$, TSP $100 \mathrm{~kg} / \mathrm{ha}$, MOP $150 \mathrm{~kg} / \mathrm{ha}$, Gypsum $80 \mathrm{~kg} / \mathrm{ha}$, Zinc Oxide $8 \mathrm{~kg} / \mathrm{ha}$. The intercultural operations were done from time to time throughout the cropping season for proper growth and development of the plants. Only one healthy seedling was kept per pit for the proper development and avoid crowd environment. Fruits were picked on the basis of horticultural maturity, size, colour and age. Frequent picking was done throughout the harvesting period. The following data such as, Days to first male flowering, Days to first female flowering, Vine length (m), Number of nodes 
per vine, Branches per vine, Fruit length $(\mathrm{cm})$, Fruit diameter $(\mathrm{cm})$, Number of fruit per plant, Weight per fruit $(\mathrm{g})$, Yield per plant $(\mathrm{kg})$, were recorded on parameters from the studied plants during the experiment. Mean data of the characters were subjected to multivariate analysis. Univariate analysis of the individual character was done for all characters under study using the mean values (Singh and Chaudhury, 1985) and was estimated using MSTAT-C computer programme. Duncan's Multiple Range Test (DMRT) was performed for all the characters to test the differences between the means of the genotypes. Mean, range and co-efficient of variation ( $\mathrm{CV} \%)$ were also estimated using MSTAT-C. For calculating the genotypic and phenotypic correlation co-efficient for all possible combinations the formula suggested by Miller et al., (1958), Johnson et al., (1955) and Hanson et al., (1956) were adopted. Broad sense heritability was estimated (Lush, 1943) by the following formula, suggested by Johnson et al., (1955). Path co-efficient analysis was done according to the procedure employed by Dewey and Lu (1959) also quoted in Singh and Chaudhary (1985), using simple correlation values. In path analysis, correlation co-efficient is partitioned into direct and indirect independent variables on the dependent variable.

\section{Results and Disussion}

The experiment was conducted to investigate the yield performance, variability, character association and yield contributing characters of seventeen bitter gourd genotypes. The result of the experiment have been presented and interpreted under the following headings. The analysis of variance indicated the existence of sufficient genetic variability among the 17 genotypes for all the plant characters (Table 2).Vine length as observed in this experiment varied significantly among the genotypes. Significantly, the highest vine length was found in $\mathrm{G}_{9}(4.53 \mathrm{~m})$ which were statistically similar with the genotypes $G_{1}, G_{2}, G_{3}, G_{5}, G_{6}, G_{7}, G_{9}$, $\mathrm{G}_{10}, \mathrm{G}_{12}, \mathrm{G}_{14}, \mathrm{G}_{16}$ and $\mathrm{G}_{17}$. On the other hand, the lowest vine length was recorded in $\mathrm{G}_{15}(2.13 \mathrm{~m})$. The results obtained related with the findings of Robinson and Decker-Walters (1997). Prasad and Sing (1992) reported a wide range of variability among the cucumber genotypes for vine length at final harvest. Phenotypic expression of any traits depends on the genotypic and the environmental variation. Generally, the higher environmental influence suppresses the expression of genetic effect. Estimation of genotypic variance was low and phenotypic variance was fairly high for vine length (Table 3).

Genotypic co-efficient of variation was found lower than the corresponding phenotypic one, which indicated the larger influence of environment. It was observed that branch per vine varied significantly among the genotypes and ranged from 30.67 to 45.60 with the mean value of 38.21 . The highest branch per vine (45.60) was found in $G_{5}$ followed by $G_{3}, G_{6}, G_{7}, G_{9}, G_{10}, G_{14}, G_{16}$ and $G_{17}$, 
where as the lowest branch per vine was observed in $\mathrm{G}_{2}$ (30.67) (Table 2). Differences between phenotypic (25.27) and genotypic (14.01) variances and also phenotypic $(81.33 \%)$ and genotypic $(60.55 \%)$ co-efficient of variation indicating environmental effect upon the expression of the characters of branch per vine (Table 3 ). The nodes per vine was observed significantly varied among the genotypes and ranged from 81.33 to 91.23 with the mean value of 85.73 (Table 2). The highest nodes per vine (91.23) was found in $\mathrm{G}_{2}$ followed by $\mathrm{G}_{3}$, $\mathrm{G}_{13}$ and $\mathrm{G}_{15}$, where as the lowest nodes/vine was observed in $\mathrm{G}_{11}$ (81.33). Considerable differences between phenotypic (12.64) and genotypic (9.98) variances and also phenotypic (38.41\%) and genotypic (34.13\%) co-efficient of variation indicating environmental effect upon the expression of the characters of nodes per vine (Table 3 ). The highest range of variation was recorded in days to first male flower opening among the genotypes and ranged from 53.77 to 61.20 days with the mean value of 56.59 days (Table 2). The plant of $\mathrm{G}_{14}$ and $\mathrm{G}_{16}$ showed the minimum days to first male flowering which was statistically similar with $\mathrm{G}_{3}, \mathrm{G}_{5}, \mathrm{G}_{7}, \mathrm{G}_{8}, \mathrm{G}_{9}, \mathrm{G}_{10}, \mathrm{G}_{11}, \mathrm{G}_{13}, \mathrm{G}_{15}$ and $\mathrm{G}_{17}$. The $\mathrm{G}_{1}$ showed the maximum days to first male flowering (61.20) followed by $\mathrm{G}_{2}, \mathrm{G}_{6}$ and $\mathrm{G}_{12}$. Differences between genotypic (3.44) and phenotypic (6.74) variances as well as genotypic $(24.68 \%)$ and phenotypic (34.54\%) co-efficient of variation (Table 3) was high indicating considerable environmental effect upon the expression of this trait. Abusaleha and Dutta (1990) found high genotypic and phenotypic (33.22 and 33.88) value for days to male flowering in bitter gourd.

The range of variation in days to first female flower opening among the genotypes ranged from 62.90 to 71.43 days with the mean value of 66.29 days (Table 2). The plants of genotype 1 showed the maximum days (71.43) to first male flowering which was statistically similar with $\mathrm{G}_{2}, \mathrm{G}_{4}, \mathrm{G}_{6}$ and $\mathrm{G}_{8}$. The genotype $G_{9}, G_{11}, G_{13}, G_{15}$ and $G_{16}$ showed the minimum days to first male flowering (62.90). Differences between genotypic (7.37) and phenotypic (9.13) variances as well as genotypic (33.37\%) and phenotypic (37.14\%) co-efficient of variation (Table 3) was high indicating considerable environmental effect upon the expression of this trait. Abusaleha and Dutta (1990a) observed that the genotypic and phenotypic variances were high (77.38 and 74.03) for days to first female flowering in bitter gourd.

Significant variation in respect of fruit length was found among the studied accessions. Genotypes 11 had the longest fruit $(21.59 \mathrm{~cm})$ and the smallest fruit was found in genotypes $5(15.55 \mathrm{~cm})$. Sharma et al.,(2000), Krisna Prasad and Singh (1994), Hormuzdi and More (1989) were found the similar results. Comparatively higher degree of genotypic variance (5.56), phenotypic (5.91) variance as well as genotypic (52.09\%) and phenotypic (53.70\%) co-efficient of variation was found for fruit length. It was similar with the findings of Saha et al.,(1992). 
Significant variation in respect of fruit diameter was found among the studied accessions. Genotypes 3 had the longest fruit diameter $(11.84 \mathrm{~cm})$ which was statistically similar to genotype 1 and genotype 2 . On the other hand, the smallest fruit diameter was found in genotypes 4 and genotype $17(9.86 \mathrm{~cm})$. Sharma et al.,(2000), Krisna Prasad and Singh (1994), Hormuzdi and More (1989) were found the similar results. Higher degree of genotypic variance $(0.25)$, phenotypic (0.40) variance as well as genotypic $(15.26 \%)$ and phenotypic $(19.31 \%)$ coefficient of variation was found for fruit diameter. It was similar with the findings of Saha et al.,(1992).

Average fruit weight varied significantly among the accessions and ranged from $102.7 \mathrm{~g}$ to $130.2 \mathrm{~g}$ where mean value was $115.30 \mathrm{~g}$. The genotype 3 had the highest fruits weight $(130.20 \mathrm{~g})$ followed by genotype 2 . On the other hand genotype 5 was carried the lowest weighty $(102.70 \mathrm{~g})$ fruits which was statistically similar with $G_{4}, G_{6}, G_{13}, G_{16}$ and $G_{17}$ (Table 2). Prasad and Singh (1992) observed high variability among the bitter gourd genotypes for this trait. High genotypic (36.75) and phenotypic (67.69) variances as well as genotypic (56.49\%) and phenotypic (76.67\%) co-efficient of variation (Table 3) for this character indicated the maximum amount of variability within the genotypes for average fruit weight and offered better scope of selection. This finding was supported by Rastogi et al.,(1990). The number of fruit per plant varied significantly among the genotypes and ranged from 19.67 to 30.00 (Table 2). The genotype 8 obtained the maximum number of fruits per plant (30.00) which was statistically similar with $\mathrm{G}_{6}, \mathrm{G}_{7}, \mathrm{G}_{9}, \mathrm{G}_{10}, \mathrm{G}_{11}$ and $\mathrm{G}_{13}$. On the other hand, the minimum number of fruits per plant (19.67) was obtained in genotype 2 followed by genotype number $\mathrm{G}_{1}, \mathrm{G}_{3}, \mathrm{G}_{5}, \mathrm{G}_{15}$ and $\mathrm{G}_{16}$ (Table 2). Anonymous (2000) reported that number of fruits per plant varied significantly among the studied cucumber lines. Slight differences were observed between genotypic (8.75) and phenotypic (13.83) variance as well as genotypic (58.79\%), phenotypic (73.92\%) co-efficient of variation indicating low environmental influence on this trait (Table 3).

The cultivars showed a significant difference in producing yield per plant and ranged from $2.2 \mathrm{~kg}$ to $3.42 \mathrm{~kg}$ (Table 3 ). From the above result, the data indicated that genotype $8(3.42 \mathrm{~kg})$ had the highest yield per plant followed by genotype $\mathrm{G}_{6}$, $G_{7}, G_{9}, G_{10}$ and $G_{14}$ which were statistically similar with each other. The genotype $2(2.2 \mathrm{~kg})$ had the lowest yield per plant followed by genotype $1, \mathrm{G}_{3}, \mathrm{G}_{5}$, $\mathrm{G}_{12}, \mathrm{G}_{15}$ and $\mathrm{G}_{16}$ which were statistically similar to each other but significantly different from the other accessions (Table 2). In a trial at BARI, Joydebpur (Anonymous, 1997) with 28 bitter gourd lines, yield per plant varied from $0.48 \mathrm{~kg}$ to $3.69 \mathrm{~kg}$, which was more or less similar to the above findings. Little differences were found between genotypic (0.12) and phenotypic (0.18) variance as well as genotypic (20.83\%) and phenotypic (25.52\%) co-efficient of variation (Table 3 ) 
resulting low environmental influence on this character. Abusaleha and Dutta (1990a) recorded low genotypic and phenotypic variances for this trait in bitter gourd.

\section{Correlation studies}

Estimation of simple correlation co-efficient was made among seven important yield components towards yield of the seventeen genotype of bitter gourd accessions. The values of ' $r$ ' and the components correlated are presented in Table 4.

Correlation co-efficient revealed that vine length had positive correlation with days to first male flowering (0.026), female flowering (0.006), fruit length (0.018), fruit diameter (0.15), individual fruit weight (0.10) and number of fruits per plant (0.178). This indicates that days to first male and female flowering, fruit length, fruit diameter, average fruit weight and number of fruits per plant will be increased with the increased of vine length (Table 4). This finding was supported by Abusaleha and Dutta (1989). Days to first male flowering had highly significant and positive correlation with days to first female flowering $(0.422)$ and negative correlation with fruit length $(-0.171)$, fruit diameter $(-0.215)$, individual fruit weight (-0.052), number of fruits per plant (-0.193) and yield per plant $(-0.184)$. This indicates that yield per plant will be decreased with the increase of days to first male flowering (Table 5). This study agrees with the finding of Li et al., (1997) and stated that days to first flowering was negatively correlated with yield per plant in selected bitter gourd inbred lines.

It was observed that days to first female flowering was not positively correlated with any of the parameter and negatively and significantly correlated with fruit length (- 0.297), fruit diameter (- 0.331), individual fruit weight $(-0.287)$ and yield per plant (- 0.332) (Table 5). Which indicate that days to first picking increased and yield per plant decreased with the increase of days to first female flowering. Ananthan and Pappiah (1997) reported that days to first female flowering were negatively correlated with total fruit yield per plant in bitter gourd. Days to first picking was also negatively correlated with yield per plant (0.145). With the respect of, the association of fruit characters, fruit length (0.202), fruit diameter (0.407), individual fruit weight (0.601) and number of fruits per plant $(0.873)$ had the high degree of significant positive association with yield per plant. This indicates that yield per plant will be increased with the increase of fruit length, fruit diameter, individual fruit weight and number of fruit per plant and average fruit weight. 


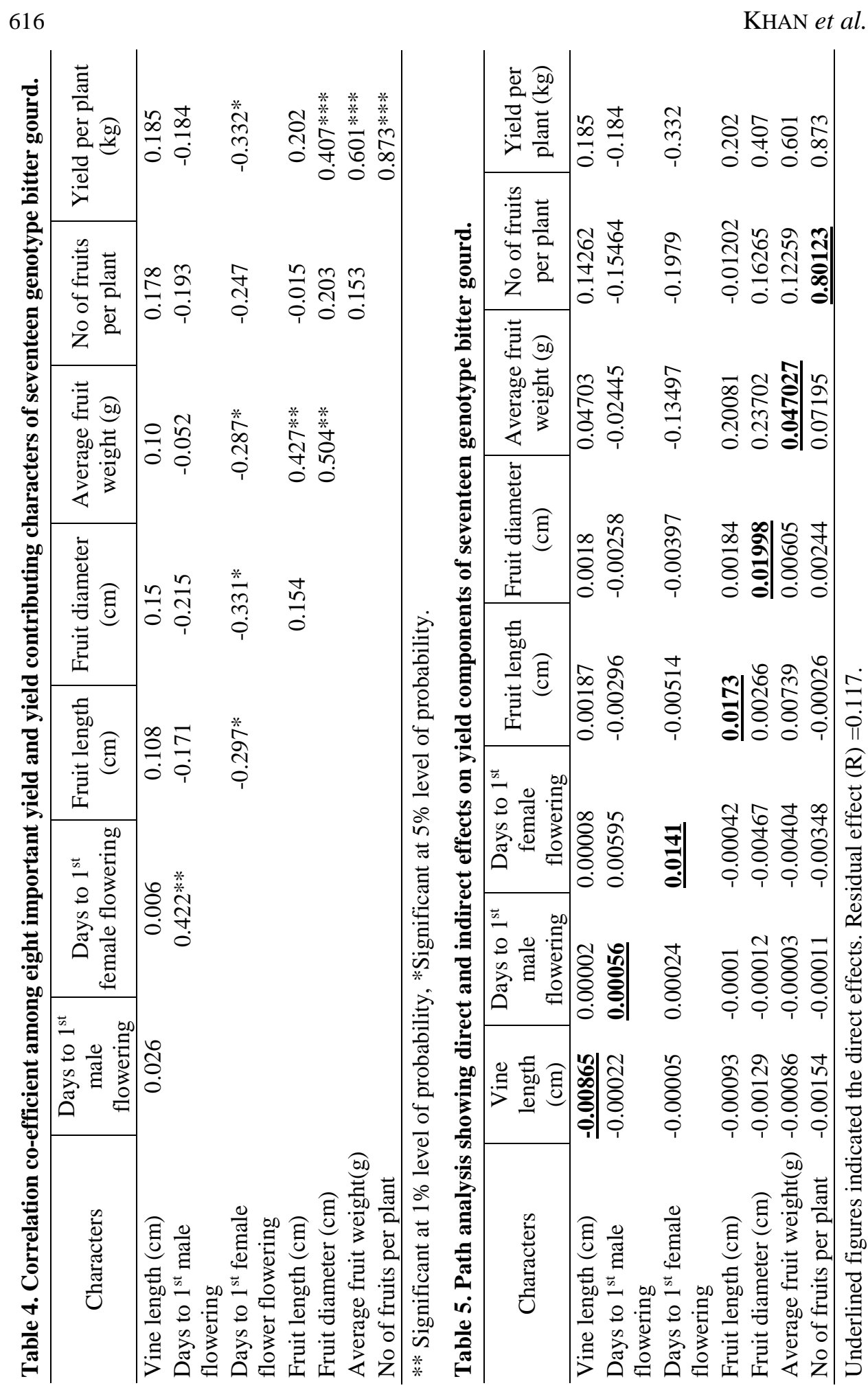


Association of characters determined by correlation co-efficient may not provide an exact picture of the relative importance of direct and indirect influence of each of the yield components towards yield. As a matter of fact, in order to find a clear picture of inter-relationship between fruit yield and yield contributing characters, direct and indirect effects were worked out using path analysis.

The results of the path analysis in table 5 revealed that direct effect of vine length on yield per plant was very low and negative $(-0.00865)$. Where as positive indirect effect of vine length on yield per plant was contributed via days to first male and female flowering, days to first picking, fruit length, fruit diameter, individual fruit weight and number of fruits per plant (Table 5). Days to first male flowering showed very lower direct and positive effect (0.00056) on yield per plant. This trait had also negative effect on yield per plant via fruit length, fruit diameter, average fruit weight and number of fruits per plant (Table 5). Days to flowering were negatively correlated with yield per plant reported by $\mathrm{Li}$ et al.,(1997). Days to first female flowering showed very low direct and positive effect (0.0141) on yield per plant. This trait had also negative effect on yield per plant via fruit length, fruit diameter, average fruit weight and number of fruits per plant (Table 5). Fruit length showed low direct and positive effect (0.0173) on yield per plant and indirect positive effect on yield per plant via fruit diameter and average fruit weight. Similar result was found for fruit diameter and average fruit weight. Number of fruits per plant showed high direct and positive effect $(0.801)$ on yield per plant (Table 5). Three characters namely average fruit weight, number of fruits per plant and average fruit length had the largest direct effect of yield per plant in bitter gourd stated by Zhang et al.,(1999). Rajput et al.,(1991) found a significant positive correlation between number of fruits per plant and fruit yield among the indigenous and exotic bitter gourd cultivars. The residual effect was 0.117 indicating that about 88 percent of the variability in yield per plant was contributed by the eight characters studied in path analysis. In the present study this residual effect towards yield might be due to many reasons such as other characters which were not studied, environmental factor and sampling errors. The path analysis carried out in the present investigation suggested that average fruit weight and number of fruits per plant which are the main components of yield should be given priority in the selection programme and as well as variety development.

\section{References}

Abusaleha and O.P. Dutta, 1989. Interrelationship of yield components in cucumber. Veg. Sci., 15:(1): 75-85.

Abusaleha and O.P. Dutta, 1990a. study on variability, heritability and scope of improvement in cucumber. Haryana J. Hort. Sci., 19(3-4):349-352.

Ananthan, M. and C.M. Pappiah, 1997 Combining ability and correlation studies in cucumber (Cucumis sativus L.). South Indian Hort., 45(1): 57-58.

Anonymous.1997. Basat Barite Sabji Utpadan (in Bengali). BARI, Gazipur, Bangladesh. P. 239. 
Anonymous, 2000. Annual Report (1999-2000). Bangladesh agricultural Research Institute, Joydebpur, Gazipur.

BBS, 2009-10, Agricultural production and area part, Bangladesh Bureau of Statistics,

Bhatt, G.M., 1973. Significant of path co-efficient analysis determining the nature of character association. Euphytica, 22: 338-343.

Dewey, D.K. and K. H. Lu, 1959. A correlation and path co-efficient analysis of components of crested wheat grass and production. Agron. J., 51: 515-518.

Hanson, C. H., H. F. Robinson and R. E. Comstock, 1956. Biometrical studies of yield in Segregation population of Korean Lespedza. Agron J., 48: 268 -272.

Hormuzdi, S. G. and T. A. More, 1989. Studies on combining ability in cucumber (Cucumis sativus L.). Indian J. Genet., 49(2): 161-166.

Johnson, H. W., H. F. Robinson and R. E. Comstock. 1955. Estimates of genetic and environmental variability in soybeans. Agron. J., 47: 314-408.

Krishna Prasad, V.S.R. and D. P. Singh, 1994. Standardized potence and combining ability in slicing cucumber (Cucumis sativus L.). Indian J. Hort., 51(1): 77-84.

Li, J.W., S.R. Sun and Y.H. Rer, 1997. Study on genetic correlation and path analysis of the main agronomic characters of cucumber. Acta Agril. Univ., Henanensis. 31(3): 244-247.

Lush, J. L., 1943. Animal Breeding Plans. Iowa State Press, Ames, Iowa, P. 437.

Meir, P. and Z. Yaniv, 1985. An in vitro study on effect of (Momordica charantia L.) on glucose uptake and glucose metabolism in rats. Plants Medica 1: 12-16

Miller, P. J., J. C.Williams, H. F. Robinson and R. E. Comstock, 1958. Estimation of genotypic and environmental variance and co-variance in upland cotton and their

Prasad, V.S.R.K. and D.P. Singh, 1992. Estimates of heritability, genetic advance and association between yield and its components in cucumber (Cucumis sativus L.). Indian J. Hort., 49(1): 62-69.

Raja, Sekaran, L.R. and Shanmugavalu, K.G., 1984. MDU1 bitter gourd. South Indian Hort. 31(1) : 47-48.

Rajput, J.C., S.B. Palve and B.M. Jamadagni, 1991. Correlation and path analysis studies in cucumber (Cucumis sativus L.). Maharastra J. Hort., 5(2): 52-55.

Rastogi, K.B., D. Arya and A. Deep, 1990. A note on interrelationship between yield and important plant characters of cucumber (Cucumis sativus L.). Veg. Sci., 17(1): 102-104.

Robinson, R. W. and D. S. Deeker-Walters, 1997. Cucurbits. University Press, Cambridge London, UK. Pp. 14-115.

Saha. R. R., B. N. Mitra, A. E. Hossain, M. Jamaluddin and A. M. M. Mosiul Hoque, 1992. Genetic variability, character association and path co-efficient analysis in pumpkin (Cucurbita moschata L). Bangladesh Hort. J. 20 (1): 59-62.

Sharma, A., K. Vidyasagar and N. K. Pathania, 2000. Studies on combining ability for earliness and marketable fruit yield in cucumber (Cucumis sativus L.). Himachal. J. Agril. Res., 26(1 \& 2): 54-61.

Singh, R. K. and B. D. Chaudhury, 1985. Biometrical methods of quantitative genetic analysis. Haryana J. Hort. Sci., 12 (2): 151-156.

Zhang, M. R. and B. R. Murty, 1999. Genetic diversity in relation to geographical distribution in pear millet. J. Pl. Breed. Genet. 75 (3 \&4): 125-128. 